\title{
NILAI-NILAI TOLERANSI DALAM ISLAM PADA BUKU TEMATIK KURIKULUM 2013
}

\author{
Evi Fatimatur Rusydiyah \\ Universitas Islam Negeri Sunan Ampel Surabaya, Indonesia \\ E-mail: evi_fatimatur@yahoo.com \\ Eka Wahyu Hidayati \\ Sekolah Tinggi Agama Islam Daruttaqwa Gresik, Indonesia \\ E-mail: eccha.ayu91@gmail.com
}

\begin{abstract}
This article discusses the values of tolerance found in the thematic text-book of 2013 curriculum. The thematic text-book has an important role in building students' character, especially regarding the values of tolerance. This article aims to answer questions concerning the design of tolerant attitude in the thematic text-book for class one of elementary school, the advantage and deficiency of the book, and solutions for thematic text-book regarding tolerant attitudes. As a study of documentation, this article deals with eight themes on thematic text-book for class one of elementary school. In analyzing the data, this study refers to seven indicators of tolerant attitude using content analysis method. This study concludes that the design of tolerant attitudes consists of respect, collaboration, help, friend-ship, equality, harmony, freedom of worship. The advantage of the text-book is its identification of seven indicators, while its deficiency is related to the presence of pictures contradictory to the values of tolerance. The solution for its deficiency is to revise the explanation of words in the negative pictures very to contradict the values of tolerance.
\end{abstract}

Keywords: Values of tolerance; thematic text-book.

\section{Pendahuluan}

Dalam proses pendidikan, penanaman nilai menjadi hal penting yang harus dilakukan oleh pendidik terhadap peserta didik untuk mencapai tujuan pendidikan itu sendiri. Hal ini termaktub dalam Undang-undang Sisdiknas No. 20 Tahun 2003, bahwa pendidikan nasional berfungsi untuk mengembangkan kemampuan dan membentuk watak serta peradaban bangsa yang bermartabat dalam 
rangka mencerdaskan kehidupan bangsa, bertujuan untuk berkembangnya potensi peserta didik agar menjadi manusia yang beriman, dan bertakwa kepada Tuhan Yang Maha Esa, berakhlak mulia, sehat, berilmu, cakap, kreatif dan mandiri, menjadi warga negara yang demokratis dan bertanggung jawab.

Salah satu nilai yang harus ditransmisikan dalam proses pendidikan adalah toleransi; sebuah sikap yang perlu dikedepankan mengingat pluralitas masyarakat Indonesia yang tidak saja karena keanekaragaman suku, ras, dan bahasa, tetapi juga dalam agama. Beberapa kasus yang terjadi dalam kurun waktu terakhir di negeri ini memberikan kesan yang kuat bagaimana perbedaan di atas menjadi alat provokasi dalam menimbulkan ketegangan dan kekerasan yang tidak semestinya terjadi. Oleh karena itu, toleransi menjadi kebutuhan mendesak yang perlu diperhatikan oleh bangsa Indonesia dengan merumuskan kembali sikap tersebut, terutama terkait keberagamaan, dengan baik dan benar di tengah masyarakat yang plural.

Kata toleransi sendiri berasal dari bahasa Latin tolerare yang berarti bertahan atau memikul. Toleran di sini diartikan dengan saling memikul walaupun pekerjaan itu tidak disukai; atau memberi tempat kepada orang lain, walaupun kedua belah pihak tidak sependapat. ${ }^{1}$ Dengan demikian, toleransi menunjuk pada adanya suatu kerelaan untuk menerima kenyataan adanya orang lain yang berbeda serta memberikan tempat kepada pendapat yang berbeda. Pada saat bersamaan sikap menghargai pendapat yang berbeda itu disertai dengan sikap menahan diri atau sabar. Oleh karena itu, di antara orang yang berbeda pendapat harus memperlihatkan sikap yang sama yaitu saling mengharagai dengan sikap yang sabar.

Dalam Kamus Besar Bahasa Indonesia, toleransi didefiniskan sebagai sikap atau sifat yang berupa menghargai serta membolehkan suatu pendirian, pendapat, pandangan, kepercayaan maupun yang lainnya yang berbeda dengan pendirian sendiri. ${ }^{2}$ Sejalan dengan definisi tersebut, Zarogin menyatakan bahwa toleransi berasal dari kata tolerance, suatu kata atau istilah yang mempunyai kesamaan dengan tolerance (Prancis), toleran₹. (Jerman), dan tolleranza (Italia). Tolerance berarti to bear or endure serta bermakna to nourish, sustain and preserve. Raphael, sebagaimana dikutip oleh Zarogin, mendefinisikan bahwa

\footnotetext{
${ }^{1}$ S.H. Siagian, Agama-Agama di Indonesia (Semarang: Satya Wacana, 1993), 115.

2 W.J.S. Poerwadarminto, Kamus Umum Bahasa Indonesia Jakarta: Balai Pustaka, 1986), 1084.
} 
tolerance is the practice of deliberately allowing or permitting a thing of which one disaproves. One can meaningfully speak of role taking, i.e. of allowing or permitting, only if one is in a position disallow.

Toleransi keagamaan dapat dipahami dengan istilah religious freedom, liberty of consciousness and belief and freedom of worship. ${ }^{3} \mathrm{Di}$ sisi lain, toleransi berarti kemampuan seseorang dalam menerima perbedaan dari orang lain. Seseorang baru bisa bersikap toleran jika dia sudah merasakan dan memahami makna keterikatan, regulasi diri (mengontrol diri), afiliasi (kerjasama), dan kesadaran. Ketika dia sudah mampu menjaga hubungan yang sehat dan dekat, merasa berada dalam sebuah kelompok, serta merasa nyaman di dalamnya, juga mampu menilai sebuah situasi, melihat kekuatan, kebutuhan, dan keterikatan dengan orang lain, maka lebih mudah baginya menerapkan sikap-sikap toleransi ini. ${ }^{4}$

Ada dua cara pandang tentang toleransi, yaitu konsepsi yang dilandasi pada otoritas negara (permission conception) dan konsepsi yang dilandasi pada kultur dan kehendak untuk membangun pengertian dan penghormatan terhadap yang lain (respect conception). Dalam hal ini Forst lebih memilih konsepsi yang kedua, yaitu toleransi dalam konteks demokrasi harus mampu membangun saling pengertian dan saling menghargai di tengah keragaman suku, agama, ras, dan bahasa. ${ }^{5}$

Sikap toleransi juga berarti membiarkan atau berlapang dada dan kesabaran hati. Di samping itu, toleransi adalah pemberian kebebasan kepada semua manusia atau warga masyarakat untuk menjalankan keyakinan dan mengatur hidup serta menentukan nasib masingmasing selama tidak melanggar dan tidak bertentangan dengan syaratsyarat asas ketertiban dan perdamaian dalam masyarakat. Sementara itu, terdapat beberapa segi toleransi yaitu mencakup mengakui hak setiap orang, menghormati keyakinan orang lain, agree in disagreement (setuju dalam perbedaan), saling mengerti, kesadaran, dan kejujuran dan jiwa falsafah Pancasila. ${ }^{6}$ Menurut Sudibjo toleransi beragama

3 Perez Zarogin, How the Idea of Religious Toleration Came to The West (Princeton: Princeton University Press, 2003), 6.

${ }^{4}$ Nurla Isna, Mencetak Karakter Anak Sejak Janin (Yogyakarta: Diva Press, 2012), 67.

5 Zuhairi Misrawi, Pandangan Muslim Moderat: Toleransi, Terorisme, dan Oase Perdamaian (Jakarta: Kompas, 2010), 3-4.

${ }^{6}$ Umar Hasyim, Toleransi dan Kemerdekaan Beragama dalam Islam sebagai Dasar Menuju Dialog dan Kerukunan Antar Agama (Surabaya: Bina Ilmu, 1991), 8. 
adalah sikap bersedia menerima keanekaragaman dan kebebasan agama yang dianut dan kepercayaan yang dihayati oleh pihak lain. ${ }^{7}$

Kerukunan antarumat beragama merupakan satu unsur penting yang harus dijaga di Indonesia yang hidup di dalamnya berbagai macam suku, ras, aliran dan agama. Untuk itu sikap toleransi yang baik diperlukan dalam menyikapi perbedaan-perbedaan tersebut agar kerukunan antarumat beragama dapat tetap terjaga, sebab perdamaian nasional hanya bisa dicapai kalau masing-masing golongan agama dapat menghormati identitas golongan lain. Maka, pendidikan menjadi garda terdepan dalam menginternalisasikan nilai toleransi kepada peserta didik. Sehingga kesepahaman, keseimbangan dan keselarasan dapat tercipta di bumi Indonesia. Berdasarkan alasan tersebut penulis melihat urgensitas untuk mengangkat tema toleransi dalam kajian ini. Untuk keperluan dimaksud penulis memfokuskan pembahasan pada nilai-nilai toleransi Islam yang terdapat dalam buku ajar Kurikulum 2013. Selain untuk menguraikan subtansi buku ajar tersebut, kajian ini juga dimaksudkan agar dapat menjadi refleksi bahwa bangsa Indonesia dianugerahi keberagaman dalam bingkai persatuan.

\section{Ajaran, Sejarah, dan Tradisi Toleransi dalam Islam}

Keragaman adalah sunnat Allâh yang tidak bisa diingkari. Allah menciptakan manusia bukan dalam keseragaman, tapi dalam keragaman dan perbedaan, baik berbeda dalam hal suku, bangsa, bahasa, warna kulit, agama, keyakinan, dan lain sebagainya. Dari perbedaan itu, Allah memerintahkan agar kita saling mengenal dan mengasihi, bukan untuk saling memusuhi. Di manapun berada, kita akan selalu berhadapan dan bertemu dengan perbedaan serta keragaman. Sebagai manusia kita tidak akan pernah bisa mendapatkan kondisi yang ideal. ${ }^{8}$

Salah satu usaha sekaligus solusi agar perdamaian bisa ditegakkan, meskipun terdapat perbedaan dalam berbagai aspek, adalah dialog. Dengan dialog masyarakat bisa mempersamakan persepsi. Dengan persepsi yang sama, paling tidak dalam sebuah komunitas yang lebih kecil khususnya di grassroot, gesekan-gesekan akibat perbedaan bisa

\footnotetext{
${ }^{7}$ Sudibjo, Toleransi Beragama Ensiklopedi Nasional Indonesia (Jakarta: Cipta Adi Pustaka, 1991), 384.

8 Zakiyuddin Baidhawy, Pendidikan Agama Berwawasan Multikultural (Jakarta: Erlangga, 2005), 78-79.
} 
diminimalisir. ${ }^{9}$ Islam sendiri melihat perbedaan di antara manusia sebagai anugerah Tuhan. Namun demikian, perbedaan benar-benar akan menjadi rahmat apabila pihak-pihak yang berbeda pendapat tetap saling menghargai, mengedepankan toleransi, tidak mengklaim kebenaran sebagai milik sendiri serta tidak melakukan penyesatan terhadap kelompok lain yang berbeda.

Dalam konteks sejarah Islam, sikap toleransi telah diletakkan pada saat awal Nabi Muhammad membangun Negara Madinah. Sesaat setelah Nabi Muhammad hijrah ke Kota Madinah, beliau segera melihat adanya pluralitas yang terdapat di tempat tersebut. Pluralitas yang dihadapi Nabi antara lain tidak hanya karena perbedaan etnis semata, tetapi juga perbedaan yang disebabkan agama. Madinah tidak bersifat homogen dalam hal agama, tetapi di Madinah di samping yang beragama Islam, terdapat pula penduduk yang beragama Yahudi, Nasrani, dan kaum Pagan. Melihat fenomena tersebut Nabi berinisiatif untuk membangun kebersamaan yang dilandasi oleh kemajemukan. Inisiatif itu kemudian melahirkan apa yang dikenal dengan Piagam Madinah. ${ }^{10}$ Dari dokumen ini diketahui bahwa Islam mengajarkan umatnya untuk saling menghormati, bukan hanya kepada sesama umat Islam, tetapi juga kepada mereka yang berbeda agama dan keyakinan. ${ }^{11}$

Kebijakan yang dilakukan oleh Rasulullah tersebut tentu tidak berangkat dari ruang kosong, melainkan dengan pijakan yang terdapat dalam al-Qur'ân. Beberapa ayat al-Qur'ân mensinyalir pentingnya sikap toleransi, seperti yang terdapat dalam Q.S. al-Baqarah [2]: 256, Q.S. al-Kahf [18]: 29, dan Q.S. Yûnus [10]: 99. Ayat-ayat tersebut menjadi dasar tentang adanya kebebasan manusia untuk menentukan pilihan atas agamanya. Prinsip-prinsip itulah yang mendasari kebijakan politik umat Islam tentang kebebasan beragama. Meskipun tidak sepenuhnya sama dengan yang ada di zaman modern ini, namun prinsip-prinsip kebebasan beragama dalam zaman klasik itu memiliki kesamaan dengan yang terjadi sekarang.

Kebijaksanaan dan kebijakan Rasulullah dalam membangun peradaban di Madinah dalam soal membangun toleransi beragama kemudian diikuti oleh 'Umar b. al-Khatțâb yang pada tahun $636 \mathrm{M}$

9 Tirmizi Taher, Berislam Secara Moderat (Jakarta: Grafindo Khazanah Ilmu, 2007), 190-197.

${ }^{10}$ Nurcholish Madjid, Islam Doktrin dan Peradaban (Jakarta: Paramadina, 1992), 195.

11 Taher, Berislam Secara Moderat, 203-204. 
menandatangani Perjanjian Aelia dengan kaum Kristen di Yerusalem. Sebagai pihak yang menang perang, 'Umar tidak menerapkan politik pembantaian terhadap pihak Kristen. Karen Armstrong memuji sikap 'Umar dan keluhuran sikap Islam dalam menaklukkan Yerusalem, yang belum pernah dilakukan para penguasa mana pun sebelumnya. 'Umar telah mengekspresikan sikap ideal kasih sayang terhadap penganut agama selain Islam. Ia memimpin satu penaklukan yang sangat damai dan tanpa tetesan darah di mana kota itu belum pernah menyaksikannya sepanjang sejarahnya yang panjang dan tragis. Saat ketika kaum Kristen menyerah tidak ada pembunuhan di sana, tidak ada penghancuran properti, tidak ada pembakaran simbol-simbol agama lain, tidak ada pengusiran atau pengambilalihan, dan tidak ada usaha untuk memaksa penduduk Yerusalem memeluk Islam. ${ }^{12}$ Jika sikap toleran terhadap penduduk yang ditaklukkan dari Kota Yerusalem itu dijadikan sebagai tanda integritas kekuatan monoteistik, maka Islam telah memulainya untuk masa yang panjang di Yerusalem, dengan sangat baik tentunya.

Toleransi Islam terhadap kaum Yahudi dan agama lain sebenarnya tercatat dengan tinta emas dalam sejarah. Setelah diusir dari Spanyol, kaum Yahudi ditampung dan dilindungi di wilayah Turki Utsmani. Sebagai contoh, di Yerusalem, di masa pemerintahan Sultan Sulaiman Agung (1520-1566), Yahudi hidup berdampingan dengan kaum Muslim. Sejumlah pengunjung Yahudi dari Eropa sangat tercengang dengan kebebasan yang dinikmati kaum Yahudi di Palestina. Pada tahun 1535, David dei Rossi, seorang Yahudi Italia, mencatat bahwa di wilayah Utsmani, kaum Yahudi bahkan memegang posisi-posisi di pemerintahan, sesuatu yang mustahil terjadi di Eropa. ${ }^{13}$

Untuk menyederhanakan konteks sejarah di atas, Nurcholis Madjid, menjelaskan bahwa nilai keislaman itu tidak hanya dipandang dari sudut internal umat Islam dalam berhubungan umat seagama tetapi bagaimana sikap orang Islam terhadap agama lain yaitu mampukah ia membangun sikap saling bertoleransi dalam beragama. Karena sebenarnya kesempurnaan agama Islam adalah karena agama ini bersifat mengayomi semua agama yang ada dan sikap itulah yang dahulu dilakukan oleh Nabi dan para sahabatnya kepada umat lain. ${ }^{14}$

\footnotetext{
12 Karen Armstrong, A History of Yerusalem: One City Three Faiths (London: Harper Collins Publishers, 1997), 228.

13 Ibid., 325-326.

14 Nurcholish Madjid, Dialog Keterbukaan: Artikulasi Nilai Islam dalam Wacana Sosial Politik Kontemporer (Jakarta: Paramadina, 1998), 267-268.
} 
Toleransi dalam kehidupan keagamaan yang ditawarkan oleh Islam begitu sederhana dan rasional. Islam mewajibkan para pemeluknya membangun batas yang tegas dalam hal akidah dan kepercayaan, sambil tetap menjaga prinsip penghargaan atas keberadaan para pemeluk agama lain dan menjaga hak-hak mereka sebagai pribadi dan anggota masyarakat. Pembatasan yang tegas dalam hal akidah atau kepercayaan ini merupakan upaya Islam untuk menjaga para pemeluknya agar tidak terjebak pada sinkretisme. Bersikap toleransi di sini memiliki batasan-batasan terutama berhubungan dengan masalah akidah. Ajaran Islam dengan tegas juga melarang para pemeluknya untuk berperilaku seperti para penganut agama lain. Namun, pada saat bersamaan Islam pun menyerukan untuk menghormati dan memandang orang lain yang berbeda agama sebagai pribadi yang utuh dengan segala hak dan kewajibannya yang mesti dihargai. Islam melarang para pemeluknya untuk mencaci-maki orang lain dan melarang segala bentuk perlakuan yang bisa mencederai kehidupan bersama dalam sebuah masyarakat.

Menurut Azyumardi Azra, dalam perspektif teologi Islam tentang kerukunan hidup antar agama, dan konsekuensinya antarumat beragama, berkaitan erat dengan dua hal, yakni: pertama, berkaitan dengan doktrin Islam tentang hubungan antarsesama manusia dan hubungan antara Islam dengan agama-agama lain. Kedua, berkaitan dengan pengalaman historis manusia sendiri dalam hubungannya dengan agama-agama yang dianut oleh umat manusia. ${ }^{15}$

Kasih dan damai merupakan jantung ajaran agama, karena merupakan kebutuhan kemanusiaan. Al-Qur'ân mencoba mengembangkan moralitas tertinggi di mana perdamaian merupakan komponen terpenting. Kata islâm sendiri diderivasi dari akar kata silm yang berarti "kedamaian". Visi kasih dalam Islam dibangun di atas dua pilar, yaitu individu dan masyarakat. Hubungan individu-individu yang saleh dan damai akan membentuk masyarakat yang ideal, yaitu masyarakat yang berdasarkan pada tiga pilar: keadilan politik, yang disebut dengan demokrasi; keadilan ekonomi, yang disebut dengan kesejahteraan dan pemerataan; dan keadilan sosial, yang disebut dengan persamaan dan tersedianya akses politik.

Islam pada esensinya memandang manusia dan kemanusiaan secara sangat positif dan optimistis. Menurut Islam, manusia berasal

15 Azyumardi Azra, Bingkai Teologi Kerukunan Hidup Antarumat Beragama: Perspektif Islam (Jakarta: Gunung Mulia, 2006), 92. 
dari satu asal yang sama, yaitu keturunan Adam dan Hawa. Dari sinilah kemudian manusia berkembang menjadi bersuku-suku, berkaum-kaum atau berbangsa-bangsa lengkap dengan kebudayaan dan peradaban khas masing-masing. Perbedaan ini mendorong manusia untuk saling mengenal dan menumbuhkan apresiasi serta penghormatan satu sama lain. Dalam pandangan Islam, perbedaan di antara umat manusia bukanlah karena warna kulit dan bangsa, tetapi hanyalah tergantung pada tingkat ketakwaan masing-masing kepada Tuhan. Inilah yang menjadi dasar perspektif Islam tentang "kesatuan umat manusia", yang pada gilirannya akan mendorong berkembangnya solidaritas antarmanusia. ${ }^{16}$ Prinsip toleransi yang diwujudkan dalam bentuk keharusan hidup rukun dapat dilihat dalam konteks persaudaraan kemanusiaan universal.

Maka toleransi dalam Islam bukan hanya doktrin, namun juga hal yang menyejarah, dan pada akhirnya menjadi tradisi. Toleransi dalam Islam merujuk pada sikap seseorang yang bersabar terhadap keyakinan filosofis dan moral orang lain yang dianggap berbeda, dapat disanggah bahkan keliru. Dengan sikap itu, ia juga tidak mencoba menghapuskan ungkapan-ungkapan yang sah dari keyakinankeyakinan orang lain. Sikap seperti ini tidak berarti setuju terhadap keyakinan-keyakinan tersebut. Selain itu, tidak berarti juga acuh tak acuh terhadap kebenaran dan kebaikan, dan tidak harus didasarkan atas pemahaman ada tidaknya Tuhan (agnotisisme) atau paham keraguan (skeptisisme), melainkan lebih pada sikap hormat terhadap maratabat manusia yang bebas. ${ }^{17}$

Toleransi yang positif adalah toleransi yang ditumbuhkan oleh kesadaran yang bebas dari segala macam tekanan atau pengaruh, serta terhindar dari sikap hipokrit. Oleh karena itu, pengertian toleransi beragama adalah pengakuan adanya kebebasan setiap warga untuk memeluk agama yang menjaga keyakinan dan kebebasannya untuk menjalankan ibadahnya. Toleransi beragama menuntut kejujuran,

\footnotetext{
16 Dalam Islam, hubungan kemanusiaan ini dikenal dengan ukhumwah islâmîyah, di dalamnya mengandung pula pengertian ukhuwwah insânîah dan ukbuwwah wataniyah. Ukhuwwah insânîah berhubungan dengan persaudaraan manusia secara universal tanpa memberdakan suku, ras, bangsa, agama, dan aspek-aspek kekhususan lainnya, sedangkan ukhuwwah watanyyah berhubungan dengan persaudaraan yang diikat oleh nasionalisme/kebangsaan tanpa membedakan agama, ras, adat istiadat, dan aspekaspek kekhususan lainnya.

17 Humaidi Abdussami' dan Masnun Tahir, Islam dan Hubungan Antar Agama (Yogyakarta: LKiS, 2007), 115.
} 
kebesaran jiwa, kebijaksanaan dan tanggung jawab sehingga menumbuhkan perasaan solidaritas dan mengeliminasi egoisme golongan. Toleransi beragama bukanlah sesuatu yang dapat dicampuradukan, melainkan mewujudkan ketenangan, saling menghargai, bahkan sebenarnya lebih dari itu, antarpemeluk agama harus dibina untuk bergotong-royong dalam membangun masyarakat demi mewujudkan kebahagiaan bersama.

Toleransi dalam pergaulan hidup antarumat beragama berpangkal dari penghayatan ajaran agama masing-masing. Demi memelihara kerukunan beragama, sikap toleransi perlu dikembangkan guna menghindari konflik. Biasanya, konflik antarumat beragama muncul disebabkan oleh sikap merasa paling benar (truth claim) dengan cara mengeliminasi kebenaran dari orang lain. ${ }^{18}$ Toleransi mengarah kepada sikap terbuka dan bersedia mengakui adanya berbagai macam perbedaan, baik dari sisi suku bangsa, warna kulit, bahasa, adatistiadat, budaya, bahasa, serta agama. Ini semua merupakan fitrah dan sunnat Allâh yang sudah menjadi ketetapan Tuhan.

Konsep toleransi yang ditawarkan Islam sangat rasional dan praktis. Namun, dalam hubungannya dengan keyakinan (akidah) dan ibadah, umat Islam tidak mengenal kata kompromi. Ini berarti keyakinan umat Islam kepada Allah tidak sama dengan keyakinan para penganut agama lain terhadap tuhan-tuhan mereka, demikian juga dengan tata cara ibadahnya, bahkan Islam melarang penganutnya mencela tuhan-tuhan dalam agama manapun. Maka kata toleransi (tasâmuḅ) dalam Islam bukanlah hal baru, tetapi sudah diaplikasikan dalam kehidupan sejak agama Islam lahir.

\section{Konsepsi Pendidikan Karakter Kurikulum Pendidikan K-13}

Sebagaimana telah disinggung di atas, Undang-Undang Nomor 20 Tahun 2003 tentang sistem Pendidikan Nasional (UU Sisdiknas) telah merumuskan indikator strategis dalam sistem pendidikan di Indonesia. Dalam memenuhi kebutuhan kompetensi abad ke-21, UU Sisdiknas juga memberikan arahan yang jelas bahwa tujuan pendidikan harus dicapai salah satunya melalui penerapan kurikulum berbasis kompetensi. Kompetensi dimaksud mencakup tiga aspek, yaitu sikap, pengetahuan, dan keterampilan, sehingga menghasilkan manusia Indonesia seutuhnya.

Kurikulum 2013 (K-13), sebagai case kajian ini, menuntut keseimbangan aspek sikap, pengetahuan, dan keterampilan. Aspek

18 Ibid., 116. 
sikap, pengetahuan, dan keterampilan yang akan dicapai pada setiap jenjang itulah yang disebut sebagai Standar Kompetensi Lulusan (SKL). Standar kompetensi lulusan diturunkan menjadi empat Kompetensi Inti (KI). KI terdiri dari sikap kepada Tuhan YME yang terdapat dalam KI pertama, sikap sosial terdapat dalam KI kedua, sikap terhadap pengetahuan dalam KI ketiga, dan sikap terhadap keterampilan KI keempat. Dengan begitu K-13 lebih ditekankan pada pendidikan karakter, terutama pada tingkat dasar, yang akan menjadi pondasi bagi tingkat berikutnya. Melalui pengembangan kurikulum 2013 yang berbasis karakter dan kompetensi, diharapkan bangsa ini menjadi bangsa yang bermartabat, dan masyarakatnya memiliki nilai tambah (added value), dan nilai jual yang bisa ditawarkan kepada orang lain di dunia, sehingga bangsa Indonesia mampu bersaing, bersanding dan bahkan bertanding dengan bangsa-bangsa lain dalam pencaturan global. Hal ini dimungkinkan jika implementasi kurikulum 2013 betulbetul dapat menghasilkan insan yang produktif, kreatif, inovatif, dan berkarakter. ${ }^{19}$

Dalam sebuah perspektif, karakter mengacu pada serangkaian sikap (attitudes), perilaku (behaviors), motivasi (motivations), ekspresi (expressiveness), simpati (sympatby) dan keterampilan (skills). ${ }^{20}$ Makna karakter itu sendiri sebenarnya berasal dari bahasa Yunani yang berarti to mark atau menandai dan memfokuskan pada aplikasi nilai kebaikan dalam bentuk tindakan atau tingkah laku, sehingga orang yang tidak jujur, kejam, rakus, dan berperilaku jelek dikatakan sebagai orang berkarakter jelek. Sebaliknya, orang yang berperilaku sesuai dengan kaidah moral ${ }^{21}$ dinamakan berkarakter mulia.

Seseorang dianggap memiliki karakter mulia apabila mempunyai pengetahuan yang mendalam tentang potensi dirinya serta mampu mewujudkan potensi itu dalam sikap dan tingkahlakunya. Adapun ciri yang dapat dicermati pada seseorang yang mampu memanfaatkan

19 E. Mulyasa, Pengembangan dan Implementasi Kurikulum 2013 (Bandung: Remaja Rosdakarya, 2013), 7.

20 Thomas P. Bailey, Jr., "Character: Study and Education", The Elementary School Teacher, Vol. 3, No. 6 (February, 1903), 359.

${ }^{21}$ Istilah "moral" berasal dari bahasa latin mores bentuk jamak dari mos yang berarti adat kebiasaan. Dalam bahasa Indonesia, moral disepadankan dengan istilah susila. Lebih lanjut yang dimaksud dengan moral ialah sesuai dengan ide-ide yang umum diterima tentang kaidah manusia mana yang baik dan wajar. Lihat Abdul Majid dan Dian Andayani, Pendidikan Karakter Perspektif Islam (Bandung: Remaja Rosdakarya, 2011), 8. 
potensi dirinya adalah terpupuknya sikap-sikap terpuji, seperti reflektif, penuh percaya diri, rasional, logis, kritis, analitis, kreatifinovatif, mandiri, berhati-hati, rela berkorban, berani, dapat dipercaya, jujur, menepati janji, adil, rendah hati, malu berbuat salah, pemaaf, berhati lembut, setia, bekerja keras, tekun, ulet, gigih, teliti, berinisiatif, berpikir positif, disiplin, antisipatif, visioner, bersahaja, bersemangat, dinamis, hemat, efisien, menghargai waktu, penuh pengabdian, dedikatif, mampu mengendalikan diri, produktif, ramah, cinta keindahan, sportif, tabah, terbuka, dan tertib. ${ }^{22}$

Seseorang yang memiliki karakter positif juga terlihat dari adanya kesadaran untuk berbuat yang terbaik dan unggul, serta mampu bertindak sesuai potensi dan kesadarannya tersebut. Dengan demikian karakter atau karakteristik adalah realisasi perkembangan positif dalam hal intelektual, emosional, sosial, etika, dan perilaku. Di sisi lain, perkembangan kepribadian juga menjadi bagian penting dari pembentukan karakter posistif. Kepribadian yang dimaksud mencakup sikap percaya diri, pikiran inklusif, inisiatif, imajinasi, dan kehendak. ${ }^{23}$ Bila peserta didik bertindak sesuai dengan potensi dan kesadarannya tersebut maka disebut sebagai pribadi yang berkarakter baik atau unggul. Indikatornya adalah mereka selalu berusaha melakukan hal-hal yang terbaik terhadap Tuhan Yang Maha Esa, diri sendiri, sesama manusia, lingkungan, negara, serta dunia internasional pada umumnya, dengan mengoptimalkan potensi (pengetahuan) dirinya disertai dengan kesadaran, emosi dan motivasi.

Di antara karakter baik yang hendak dibangun dalam kepribadian peserta didik adalah bisa bertanggung jawab, jujur, dapat dipercaya, menepati janji, ramah, peduli kepada orang lain, percaya diri, pekerja keras, bersemangat, tekun, tidak mudah putus asa, bisa berpikir rasional dan kritis, kreatif dan inovatif, dinamis, bersahaja, rendah hati, tidak sombong, sabar, cinta ilmu dan kebenaran, rela berkorban, berhati-hati, bisa mengendalikan diri, tidak mudah terpengaruh oleh informasi yang buruk, mempunyai inisiatif, setia, menghargai waktu, dan bisa bersikap adil. ${ }^{24}$

Pendidikan karakter dalam kurikulum 2013 bertujuan untuk meningkatkan mutu proses dan hasil pendidikan, yang mengarah pada

22 Ibid.

23 World Affairs Institute, "Character Education in Our Public Schools", The Advocate of Peace (1894-1920), Vol. 79, No. 10 (November, 1917), 290.

${ }^{24}$ Akhmad Muhaimin Azzet, Urgensi Pendidikan Karakter di Indonesia (Yogyakarta: ArRuzz Media, 2011), 29. 
budi pekerti dan akhlak mulia peserta didik secara utuh, terpadu, dan seimbang sesuai dengan standar kompetesi lulusan pada setiap satuan pendidikan. Melui implementasi kurikulum 2013 yang berbasis kompetensi sekaligus berbasis karakter dengan pendekatan tematik dan kontekstual diharapkan peserta didik mampu secara mandiri meningkatkan dan menggunakan pengetahuannya, mengkaji dan menginternalisasi serta mempersonalisasi nilai-nilai karater dan akhlak mulia sehingga terwujud dalam perilaku sehari-hari. ${ }^{25}$

Secara konseptual, pendidikan karakter di Indonesia bertujuan mengembangkan nilai-nilai yang membentuk karakter bangsa, yaitu Pancasila, yang meliputi: (1) Mengembangkan potensi peserta didik agar menjadi manusia berhati baik, berpikiran baik, dan berperilaku baik; (2) Membangun bangsa yang berkarakter Pancasila; (3) Mengembangkan potensi warganegara agar memiliki sikap percaya diri, bangga pada bangsa dan negaranya serta mencintai umat manusia. Sementara, fungsi pendidikan karakter sendiri adalah: (1) Membangun kehidupan kebangsaan yang multikultural; (2) Membangun peradaban bangsa yang cerdas, berbudaya luhur, dan mempu berkontribusi terhadap pengembangan kehidupan ummat manusia, mengembangkan potensi dasar agar berhati baik, berpikiran baik, dan berperilaku baik serta keteladanan baik; (3) Membangun sikap warganegara yang mencintai damai, kreatif, mandiri, dan mampu hidup berdampingan dengan bangsa lain dalam suatu harmoni. ${ }^{26}$ Karakter-karakter tersebut dapat disemai dengan proses pendidikan yang baik. Maka seluruh pihak yang menopang penanaman karaktermulai dari pemerintah hingga intitusi pendidikan-harus merumuskan sebuah formulasi yang terkonsep dengan baik untuk menentukan kebijakan, pengawasan dan mengembangkan metode pendidikan karakter di setiap institusi pendidikan. ${ }^{27}$

Dalam implementasi kurikulum 2013, pendidikan karakter dapat diintegrasikan dalam seluruh pembelajaran pada setiap bidang studi yang teradapat dalam kurikulum. Materi pembelajaran yang berkaitan dengan norma atau nilai-nilai pada setiap bidang studi perlu dikembangkan, dieksplisitkan, dan dihubungkan dengan konteks

25 Tim Kemendikbud, Kurikulum 2013: Kompetensi Dasar (Jakarta: Kemendikbud, 2013), 1-2.

26 Tim Penyusun, Panduan Pelaksanaan Pendidikan Karakter (Jakarta: Kementerian Pendidikan Nasional, 2011), 3.

27 David Snedden, "The Improvementof Character Education", The Journal of Education, Vol. 88, No. 6 (August 8, 1918), 145. 
kehidupan sehari-hari. Dengan demikian, pendidikan nilai dan pembentuknan karakter tidak hanya dilakukan pada tataran kognitif, tetapi menyentuh internalisasi dan pengamalan nyata dalam kehidupan sehari-hari. Pendidikan karakter pada tingkat satuan pendidikan mengarah pada pembentukan budaya sekolah/madrasah, yaitu nilainilai yang melandasi perilaku, tradisi, kebiasaan sehari-hari, serta simbol-simbol yang dipraktikkan oleh semua warga sekolah dan masyarakat sekitarnya.

Budaya sekolah merupkan ciri khas, karakter/watak, dan citra sekolah tersebut di mata masyarakat luas. Pada umumnya pendidikan karakter menekankan pada keteladanan, penciptaan lingkungan, dan pembiasaan melalui berbagai tugas keilmuan dan kegiatan kondusif. Dengan demikian, apa yang dilihat, didengar, dirasakan dan dikerjakan oleh peserta didik dapat membentuk karakter mereka. Selain menjadikan keteladanan dan pembiasaan sebagai metode pendidikan utama, penciptaan iklim dan budaya serta lingkungan yang kondusif juga sangat penting serta turut membentuk karakter peserta didik.

Kurikulum 2013 yang berbasis karakter dan kompetensi, pada tataran implementasinya, melibatkan semua komponen (stakeholders), termasuk komponen-komponen yang ada pada sistem pendidikan itu sendiri. Komponen-komponen tersebut antara lain kurikulum, rencana pembelajaran, proses pembelajaran, mekanisme penilaian, kualitas hubungan, pengelolaan pembelajaran, pengelolan sekolah /madrasah, pelaksanaan pengembangan diri peserta didik, pemberdayaan sarana prasarana, pembiayaan, serta etos kerja seluruh warga dan lingkungan sekolah/madrasah.

Kurikulum 2013 dalam implementasinya jua menuntut kerjasama yang optimal di antara para guru, sehingga memerlukan pembelajaran berbentuk tim dan menuntut kerja sama yang kompak di antara para anggota tim. Kerjasama antara para guru sangat penting dalam proses pendidikan yang akhir-akhir ini mengalami perubahan yang sangat pesat. Kurikulum 2013 yang ditawarkan merupakan bentuk operasional penataan kurikulum dan SNP yang akan memberikan wawasan baru terhadap sistem yang sedang berjalan selama ini.

\section{Buku Teks Kurikulum 2013 dan Toleransi Keberagaman}

Sikap toleransi perlu ditanamkan sejak dini, dikarenakan kita hidup di dalam suatu negara yang diwarnai dengan berbagai ragam budaya, adat, suku bangsa, dan agama dengan semboyan "Bhinneka Tunggal Ika". Keberagaman ini harus selalu dijaga agar masing- 
masing individu dengan berbagai perbedaan itu bisa tetap bersatu, berdampingan, dan saling melindungi. Semua ini bisa terjadi jika setiap individu masyarakat memiliki sikap toleran yakni saling menghormati dan menghargai. Tanpa adanya sikap toleran, keberagaman itu akan memunculkan konflik, permasalahan dan pertentangan yang sangat merugikan.

Berdasarkan Peraturan Menteri Pendidikan Nasional Nomor 2 tahun 2008 mengenai buku teks sekolah pada pasal 1 dijelaskan bahwa buku teks adalah buku acuan wajib untuk digunakan di satuan pendidikan dasar dan menengah atau perguruan tinggi yang memuat materi pembelajaran dalam rangka peningkatan keimanan dan ketakwaan, akhlak mulia dan kepribadian, kemampuan penguasaan ilmu pengetahuan dan teknologi, peningkatan kepekaan dan kemampuan estetis, peningkatan kemampuan kinetis, dan kesehatan yang disusun berdasarkan standar nasional pendidikan. Taringan menyebutkan bahwa buku teks adalah buku pelajaran dalam bidang studi tertentu, yang merupakan buku standar, yang disusun oleh para pakar dalam bidang itu untuk maksud-maksud dan tujuan instruksional, yang diperlengkapi dengan sarana-sarana pengajaran yang serasi dan mudah dipahami oleh para pemakainya di sekolahsekolah dan perguruan tinggi sehingga dapat menunjang sesuatu program pengajaran. ${ }^{28}$

Buku teks merupakan sekumpulan tulisan yang dibuat secara sistematis oleh pakar dalam bidang masing-masing berisi materi pelajaran dalam bidang tertentu dan telah memenuhi indikator sesuai dengan kurikulum atau standar yang telah ditentukan sebelumnya sebagai pegangan pendidik serta alat bantu bagi peserta didik dalam memahami materi belajar dalam pembelajaran yang dilengkapi dengan sarana-sarana pengajaran yang serasi dan mudah dipahami oleh para pemakainya di sekolah-sekolah dan perguruan tinggi sehingga dapat menunjang suatu program pengajaran.

Penelitian ini menggunakan studi dokumentasi. Penelitian ini dilakanakan untuk mencari desain nilai-nilai sikap toleran, kelebihan dan kekurangan sikap toleran, dan solusinya yang terdapat dalam buku teks tematik K-13 bagi kelas satu SD. Pada K-13, buku teks kelas satu SD menggunakan pembelajaran buku tematik. Pembelajaran tematik sendiri dimaknai sebagai pola pembelajaran yang mengintegrasikan pengetahuan keterampilan, kreativitas, nilai, dan sikap pembelajaran

${ }^{28}$ H.G. Taringan, Telaah Buku Teks Bahasa Indonesia (Bandung: Angkasa, 1986), 13. 
dengan menggunakan tema. ${ }^{29}$ Dengan mengintegrasikan semua hal tersebut diharapkan dapat mempermudah peserta didik dalam memahami buku teks tematik yang ada dalam kegiatan pembelajaran sehingga materi-materi yang ada tidak hanya mengasah kemampuan intelektual akan tetapi juga dapat menanamkan dan mengembangkan sikap-sikap yang baik, termasuk di dalamnya sikap toleransi.

Pengembangan sikap toleran pada peserta didik sekolah dasar memerlukan beberapa hal yang perlu diperhatikan dan disesuaikan dengan keadaan peserta didik. Oleh karena itu, masing-masing komponen tidak boleh berjalan secara terpisah, tetapi harus berjalan secara beriringan, sehingga diperlukan pengelolaan pengajaran yang baik yang telah dipertimbangkan dan dirancang secara sistematis. Hal ini merupakan bagian dari solusi untuk mengurangi dan mengatasi problematika yang melanda dunia pendidikan, terutama yang berkenaan dengan pengembangan sikap. Realitas inilah yang menarik peneliti untuk meneliti tentang nilai-nilai toleransi pada buku teks tematik K-2013.

Dalam ranah pendidikan, toleransi merupakan bentuk refleksi dari sikap hormat. Meskipun toleransi dapat berbaur menjadi sebuah relativisme netral untuk menghindari berbagai prasangka yang menyangkut etika, toleransi pada akhirnya adalah tanda dari salah satu arti kehidupan yang beradab. Toleransi merupakan sebuah sikap yang memiliki kesetaraan dan tujuan bagi mereka yang memiliki pemikiran, ras, dan keyakinan berbeda-beda. Toleransi adalah sesuatu yang membuat dunia setara dari berbagai bentuk perbedaan. ${ }^{30}$

Sikap toleran dalam pendidikan karakter yang dikembangkan oleh Lickona, sebagai dasar teori dari peneilitian ini, adalah saling pengertian, menghargai dan menghormati perbedaan (menghormati orang lain), senang bekerjasama dengan orang lain, senang membantu orang lain, senang berteman dengan orang lain (senang berteman), kesetaraan dalam perbedaan (bersikap adil), hidup nyaman dan rukun, dan kebebasan menjalankan keyakinan (tidak memaksakan agama). ${ }^{31}$

Sementara itu menurut Kementerian Pendidikan dan Kebudayaan, KI bagi kelas satu SD/MI dalam buku teks K-2013 tematik meliputi KI 1, yaitu menerima dan menjalankan ajaran agama yang dianutnya,

29 Andi Prastowo, Pengembangan Bahan Ajar Tematike (Yogyakarta: Diva Press, 2013), 23.

30 Thomas Lickona, Educating for Character: How You Respect and Responsibility, terj. Juma Abdu Wamaungo (Jakarta: Bumi Aksara, 2012), 74-75.

${ }^{31}$ Ibid. 
dan; KI 2, yaitu memiliki perilaku jujur, disiplin, tanggung jawab, santun, peduli, dan percaya diri, dalam berinteraksi dengan keluarga, teman, dan guru.

\section{Konsep dan Implementasi Nilai-nilai Toleransi Buku Teks K-13}

Desain sikap toleran pada buku teks tematik kelas satu SD meliputi sikap menghormati orang lain, bekerjasama, senang membantu, senang berteman, bersikap setara (adil), hidup rukun (nyaman), dan kebebasan menjalankan ibadah. Desain sikap toleran yang penulis temukan dalam buku teks tematik kelas satu SD K-13 diilustrasikan dalam diagram berikut.

\section{Diagram 1.1:}

Desain Nilai Toleransi dalam Buku Teks Tematik Kelas Satu SD

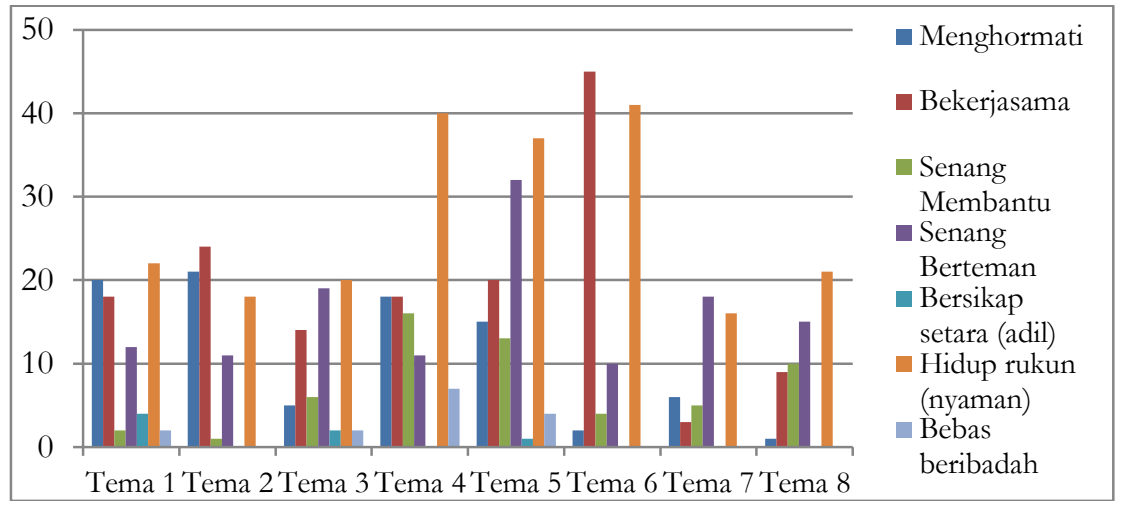

Pada diagram di atas dapat dilihat bahwa indikator tertinggi berada pada tema enam yakni senang bekerjasama. Hal ini dikarenakan tema enam memuat materi yang berhubungan dengan lingkungan bersih, sehat dan asri. Dalam hal ini, anak disuguhkan kata maupun gambar senang bekerjasama dengan orang lain untuk menjaga lingkungan agar selalu bersih.

Sementara itu, indikator menghormati orang lain banyak ditemukan pada tema satu, tema dua, tema empat, dan tema lima dikarenakan indikator-indikator tersebut memuat materi-materi yang berhubungan dengan interaksi dengan orang lain yakni "materi diriku", "kegemaranku", "keluargaku" dan "pengalamanku". Sedangkan pada tema tiga, tema enam, tema tujuh, dan tema delapan hanya sedikit atau jarang ditemui indikator menghormati orang lain. Indikator senang membantu, banyak ditemukan pada tema empat, tema lima, tema delapan, dan tema tiga dikarenakan pada indikator tersebut memuat materi-materi yang berhubungan dengan sikap 
senang membantu orang lain yakni materi keluargaku, pengalamanku, peristiwa alam dan kegiatanku. Sedangkan pada tema satu, tema dua, tema enam, dan tema tujuh hanya sedikit ditemukan indikator senang membantu orang lain. Indikator senang berteman ditemukan pada semua tema yaitu pada tema satu sampai dengan tema delapan di mana tema-tema tersebut memuat materi-materi yang berhubungan dengan indikator senang berteman dengan orang lain, seperti "diriku", "kegemaranku", "kegiatanku", "keluargaku”, "pengalamanku”, "lingkungan bersih sehat dan asri", "benda. hewan dan tanaman disekitarku" dan "peristiwa alam".

Sedangkan pada tema enam, tema tujuh dan tema delapan terdapat indikator terendah yakni sikap setara (adil) dan bebas beribadah. Hal ini dikarenakan tema tujuh, misalnya, memuat materi yang berhubungan dengan benda, hewan dan tanaman di sekitarku. Jadi, materi tersebut tidak memiliki kaitan dengan sikap bebas beribadah dan sikap adil.

Dari diagram di atas dapat ditarik kesimpulan bahwa indikator sikap toleran yang tertinggi pada setiap tema adalah sebagai berikut.

\section{Diagram 1.2:}

Sikap Toleransi Tertinggi dalam Buku Teks Tematik Kelas Satu SD

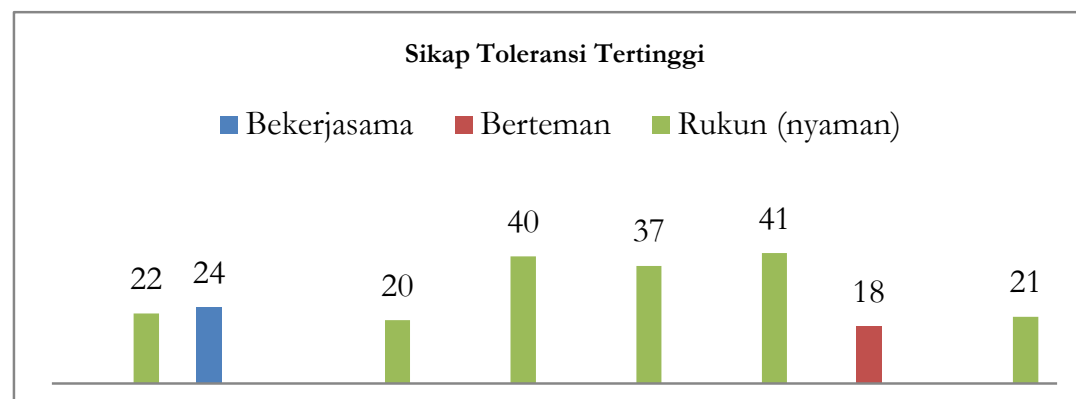

Tema 1 Tema 2 Tema 3 Tema 4 Tema 5 Tema 6 Tema 7 Tema 8

Melihat diagram di atas diketahui bahwa nilai sikap toleran tertinggi terdapat pada indikator hidup rukun (nyaman). Dalam hal ini, hidup rukun (nyaman) terdapat pada hampir semua tema, kecuali tema dua dan tujuh. Dalam buku teks K-13 untuk SD, hidup rukun (nyaman) ditunjukkan dengan adanya kata maupun gambar yang menunjukkan sikap senang hidup rukun (nyaman) dengan orang lain.

Pada tema kedua terlihat bahwa yang lebih unggul adalah indikator kedua, yakni senang bekerjasama dengan orang lain. Senang bekerjasama pada indikator tersebut didukung dengan kata dan 
gambar tentang seseorang yang gemar bekerjasama dengan orang lain. Sedangkan pada tema tujuh indikator tertinggi terdapat pada indikator keempat, yaitu senang berteman dengan orang lain. Senang berteman dengan orang lain dalam tema ini ditunjukkan dengan kata dan gambar yang menunjukkan sikap senang berteman dengan orang lain.

Berdasarkan teori dan hasil penelitian nilai karakter yang terdapat dalam buku tematik K-2013, penulis memaparkan hasil analisis bahwa desain sikap toleran yang terdapat pada buku teks tematik kelas satu SD meliputi sikap menghormati orang lain, bekerjasama, senang membantu, senang berteman, bersikap setara (adil), hidup rukun, dan kebebasan menjalankan ibadah. Dari ketujuh sikap toleran tersebut sikap hidup rukun merupakan sikap yang paling dominan. Hal ini sesuai dengan ayat Q.S. al-Mumtaḥanah [60]: 7-8.

Dalam hubungannya dengan orang-orang yang tidak seagama, Islam mengajarkan agar umat Islam berbuat baik dan bertindak adil. Dengan kata lain, berbuat baik dan adil harus ditujukan kepada siapapun selama orang lain tersebut tidak memerangi umat Islam karena agama yang dianut. Al-Qur'ân, sebagai sumber ajaran Islam, sangat menekankan umat Islam untuk mengutamakan terciptanya suasana perdamaian, sehingga rasa kasih sayang muncul baik sesama kaum Muslim maupun dengan umat beragama lain. Islam bahkan tidak melarang umatnya untuk menjalin kerjasama sosial yang baik dengan umat beragama lain. Di sini ditegaskan kembali bahwa toleransi yang diajarkan oleh Islam adalah toleransi yang terbatas pada hubungan sosial dan bukan dalam hal penyampuradukan akidah/keimanan.

Kembali kepada buku teks tematik K-13 bagi kelas satu SD di mana terdapat beberapa kelebihan pada konten dalam kedelapan tema yang diteliti, terutama teridentifikasinya tujuh level sikap toleran yang berkesesuaian dengan desain sikap toleran yang penulis ajukan. Namun demikian penulis menemukan adanya kelemahan dalam buku tersebut, yaitu adanya beberapa gambar yang-menurut hemat penulis-tidak sesuai dengan penanaman karakter toleransi. Selain itu juga terdapat beberapa gambar yang tidak sesuai dengan keterangan yang ada di buku. Oleh karena itu, penulis menyarankan agar dilakukan revisi baik terhadap gambar maupun kata keterangan pada gambar agar pesan penanaman sikap toleran sampai dan dipahami dengan baik oleh peserta didik. Adapun beberapa kata keterangan 
yang tidak sesuai dengan gambar juga perlu direvisi agar sesuai dengan ilustrasi yang ditampilkan.

Penelitian ini menemukan bahwa pembelajaran pada buku tematik K-13 menitikberatkan pada penanaman tiga nilai sikap toleran, yaitu senang bekerjasama, senang berteman dengan orang lain dan senang hidup rukun (nyaman) dengan orang lain. Tiga nilai tersebut sejalan dengan teori perkembangan anak usia 6-8 tahun di mana pada masa tersebut anak memasuki masa sosialisasi. Dari tiga nilai di atas, sikap toleran senang hidup rukun (nyaman) dengan orang lain menjadi aspek yang menonjol. Penanaman sikap ini sangat diperlukan dalam perkembangan anak, khususnya dalam konteks bahwa Indonesia adalah bangsa yang majemuk dan terkenal dengan keanekaragaman budaya, suku, adat-istiadat, bahasa dan agama. Dengan penanaman sikap tersebut diharapkan peserta didik dapat berinteraksi dengan baik, terutama di lingkungan keluarga, sekolah dan masyarakatnya.

Penanaman sikap hidup rukun bersama orang lain juga memiliki relevansi dengan teori sosiologi menurut Charlotte Buhler. Buhler, sebagaimana dikutip oleh Sobur, menjelaskan bahwa saat berusia 5-8 tahun seorang anak berada pada fase ketiga. Fase ini bisa dikatakan sebagai masa sosialisasi. Pada masa ini, anak mulai memasuki masyarakat luas (misalnya, taman kanak-kanak, pergaulan dengan teman-teman sepermainan, dan sekolah dasar). Anak juga mulai belajar mengenal dunia sekitar secara objektif. Ia mulai belajar mengenal arti prestasi, pekerjaan, dan tugas-tugas kewajiban. Jadi yang penting diperhatikan pada fase ini adalah berlangsungnya proses sosialisasi. ${ }^{32}$

Di akhir pemaparan tentang buku teks tematik K-13 ini penulis ingin menggarisbawahi bahwa materi-materi yang disajikan perlu terus diperkaya dalam membangun nilai karakter toleransi maupun 18 nilai karakter lainnya. Penempatan gambar dan teks perlu disesuaikan agar peserta didik lebih mudah dan jelas dalam memahami materi. Dalam kaitan ini, kepala sekolah dan guru hendaknya lebih selektif dalam memilih bahan ajar yang digunakan dan menambah buku-buku lain yang relevan. Selanjutnya, penting bagi pihak sekolah, terutama guru, untuk bekerja sama secara baik dan koordinatif dengan orang tua dalam ikut serta memberikan pengawasan dan arahan agar penanaman nilai karakter terhadap peserta didik dapat berjalan dengan baik dan mencapai hasil yang optimal.

32 Alex Sobur, Psikologi Umum (Bandung: Pustaka Setia, 2003), 132. 


\section{Penutup}

Nilai-nilai toleransi dalam Islam yang terdapat pada buku teks tematik kelas satu SD meliputi sikap menghargai kepada orang lain, bekerjasama, senang membantu, senang berteman, bersikap setara, hidup rukun, dan kebebasan menjalankan ibadah. Ketujuh sikap toleran di atas yang paling dominan adalah sikap hidup rukun. Kelebihan sikap toleran pada buku teks tematik kelas satu SD yang terdapat pada tema 1-8 teridentifikasinya tujuh level toleransi sesuai dengan desain sikap toleran. Kelemahan sikap toleran yakni terdapat beberapa gambar yang bertentangan dengan karakter toleransi dan terdapat beberapa gambar yang tidak sesuai dengan keterangan yang ada di buku. Solusi kelemahan sikap toleran pada buku teks tematik kelas satu SD adalah dengan memberikan revisi keterangan kata pada gambar negatif agar peserta didik tidak mengikuti gambar negatif yang tidak sesuai dengan sikap toleran. Materi pada buku teks tematik kurikulum 2013 perlu ditingkatkan dalam membangun nilai karakter toleransi maupun 18 nilai karakter lainnya. Semestinya guru harus bekerjasama dengan pihak orang tua untuk terlibat dalam memberikan pengawasan dan arahan agar penanaman nilai karakter peserta didik dapat berjalan sesuai dengan yang diharapkan.

\section{Daftar Rujukan}

Abdussami', Humaidi dan Tahir, Masnun. Islam dan Hubungan Antar Agama. Yogyakarta: LKiS, 2007.

Armstrong, Karen. A History of Yerusalem: One City Three Faiths. London: Harper Collins Publishers, 1997.

Azra, Azyumardi. Bingkai Teologi Kerukunan Hidup Antarumat Beragama: Perspektif Islam. Jakarta: Gunung Mulia, 2006.

Azzet, Akhmad Muhaimin. Urgensi Pendidikan Karakter di Indonesia. Yogyakarta: Ar-Ruzz Media, 2011.

Baidhawy, Zakiyuddin. Pendidikan Agama Berwawasan Multikultural. Jakarta: Erlangga, 2005.

Bailey, Jr., Thomas P. "Character: Study and Education", The Elementary School Teacher, Vol. 3, No. 6, February, 1903.

Hasyim, Umar. Toleransi dan Kemerdekaan Beragama dalam Islam sebagai Dasar Menuju Dialog dan Kerukunan Antar Agama. Surabaya: Bina Ilmu, 1991.

Institute, World Affairs. "Character Education in Our Public Schools", The Advocate of Peace (1894-1920), Vol. 79, No. 10, November, 1917. 
Isna, Nurla. Mencetak Karakter Anak Sejak Janin. Yogyakarta: Diva Press, 2012.

Kemendikbud, Tim. Kurikulum 2013: Kompetensi Dasar. Jakarta: Kemendikbud, 2013.

Lickona, Thomas. Educating for Character: How You Respect and Responsibility, terj. Juma Abdu Wamaungo. Jakarta: Bumi Aksara, 2012.

Madjid, Nurcholish. Dialog Keterbukaan: Artikulasi Nilai Islam dalam Wacana Sosial Politik Kontemporer. Jakarta: Paramadina, 1998.

Madjid, Nurcholish. Islam Doktrin dan Peradaban. Jakarta: Paramadina, 1992.

Majid, Abdul dan Andayani, Dian. Pendidikan Karakter Perspektif Islam. Bandung: Remaja Rosdakarya, 2011.

Misrawi, Zuhairi. Pandangan Muslim Moderat: Toleransi, Terorisme, dan Oase Perdamaian. Jakarta: Kompas, 2010.

Mulyasa, E. Pengembangan dan Implementasi Kurikulum 2013. Bandung: Remaja Rosdakarya, 2013.

Penyusun, Tim. Panduan Pelaksanaan Pendidikan Karakter. Jakarta: Kementerian Pendidikan Nasional, 2011.

Poerwadarminto, W.J.S. Kamus Umum Bahasa Indonesia. Jakarta: Balai Pustaka, 1986.

Prastowo, Andi. Pengembangan Bahan Ajar Tematik. Yogyakarta: Diva Press, 2013.

Siagian, S.H. Agama-Agama di Indonesia. Semarang: Satya Wacana, 1993.

Snedden, David. "The Improvementof Character Education", The Journal of Education, Vol. 88, No. 6, August 8, 1918.

Sobur, Alex. Psikologi Umum. Bandung: Pustaka Setia, 2003.

Sudibjo. Toleransi Beragama Ensiklopedi Nasional Indonesia. Jakarta: Cipta Adi Pustaka, 1991.

Taher, Tirmizi. Berislam Secara Moderat. Jakarta: Grafindo Khazanah Ilmu, 2007.

Taringan, H.G. Telaah Buku Teks Bahasa Indonesia. Bandung: Angkasa, 1986.

Zarogin, Perez. How the Idea of Religious Toleration Came to The West. Princeton: Princeton University Press, 2003. 